Revista Iberoamericana, Vol. LXXII, Núm. 214, Enero-Marzo 2006, 199-225

\title{
¡CON LEER NO BASTA! LÍMITES DE LA CIUDAD LETRADA (LA CULTURA DE LAS EXPOSICIONES)
}

\author{
POR \\ BEATRIZ GonZÁLEZ-STEPHAN \\ Rice University
}

\begin{abstract}
Ningún libro ni ninguna colección de libros puede enseñar a los maestros de agricultura lo que verán por sus propios ojos en los terrenos de la Exposición (...) Ya las Exposiciones no son lugares de paseo. Son avisos: son lecciones enormes y silenciosas: son escuelas.
\end{abstract}

José Martí

\section{LA EDUCACIÓN DE LA MIRADA}

Durante los 15 años que José Martí pasó en la América del Norte (1881-1895) desarrolló una entusiasta afición por toda clase de Exposiciones y ferias, sin olvidar su profundo interés por la Exposición de París de 1889, que no llegó a visitar, pero sí reseñar en su revista mensual La Edad de Oro. Para Martí el espacio de las Exposiciones era el lugar de la quintaesencia de las manifestaciones de la nueva cultura material de la modernidad. Eran literalmente los escenarios donde se congregaban los más recientes progresos tecnológicos, la galería de artefactos que permitirían optimizar en algún futuro las condiciones de la vida cotidiana, convocar los bienes naturales y simbólicos (desde la gama infinita e impensada de materias primas hasta objetos de arte) de regiones y lugares desconocidos. Eran escenarios donde se condensaba el gesto más contundente de la cultura escópica del siglo. Eran teatros donde los actores sociales habían desaparecido detrás de un mundo proliferante de cosas, de cosas hechas por otras cosas, donde adquirían el resplandor de objetos deseables, de mercancías, iridizadas por la iluminación eléctrica que refrendaba los alcances del progreso material.

Martí, no menos atrapado por ese fascinante espectáculo, pero al tiempo no menos alerta del drama humano que escondía esta fase del capitalismo (su preocupación por los obreros norteamericanos cuyas vidas quedaban cosificadas en este nuevo mundo de cosas), valoró con una sensibilidad abierta y no ortodoxa -“benjamineana” si se quiereeste nuevo orden epistemológico que se abría en las Exposiciones, y que al calor de una sintaxis que articulaba cosas, luces, galerías y multitudes, obligaba a resituar todo el proyecto de la República de las Letras, y repensar vías alternativas y no ilustradas de las equivalencias entre la formación de ciudadanías y el proyecto nacional. En otras palabras -y aunque se seguía apostando a la validez de la razón ilustrada-, lo que Martí cuestionaba era la eficacia -al menos para la América Latina- del proyecto modernizador a través de 
la difusión de la cultura del libro. Al respecto, su pensamiento fue tajante no sólo en su ya conocido ensayo “Nuestra América”, sino también en las crónicas que dedicara al tema de las Exposiciones:

\begin{abstract}
Se está cometiendo en el sistema de educación en América Latina un error gravísimo: en pueblos que viven casi por completo de los productos del campo, se educa exclusivamente a los hombres para la vida urbana, y no se les prepara para la vida campesina (...) con el actual sistema de educación se está creando un gran ejército de desocupados y desesperados (...) Y cada día, con la educación puramente literaria que se viene dando en nuestros países, se añade a la cabeza, y se quita al cuerpo. Por todas estas razones decimos que, como cuanto se tiene aprendido y se está ensayando en agricultura va a estar expuesto durante tiempo suficiente para estudiarlo en la Exhibición de New Orleans. (Martí, "Nuestra América”, VIII: 369)
\end{abstract}

Entonces, las Exposiciones se tornaban para Martí en verdaderas escuelas, y por tanto, en espacios de una pedagogía que implicaba una política del ojo, la educación de la mirada. Ya no aprender a leer la letra escrita, sino aprender a leer imágenes, signos visuales, toda una semiótica de las cosas; y por inducción, obtener inferencias prácticas y funcionales. Enseñar -como dirá en la misma crónica - “a que los maestros de agricultura vean por sus propios ojos en los terrenos de la Exposición” (Martí, "Nuestra América”, VIII: 368, énfasis nuestro). En este sentido, se podía aprovechar la fuerza hegemónica de la cultura dominante -porque las Exposiciones eran espacios donde se densificaba la lógica del capitalismo euroccidental, al tiempo de aparecer bajo reglas que horizontalizaban la jerarquía piramidal del sistema- para rearticular productivamente al nuevo sujeto de la modernidad: las masas de obreros, de campesinos, de indios, de sectores medios urbanos, de mujeres y también de niños. No es casual que el texto paradigmático, en este orden de tópicos, "La Exposición de París”, estuvo dedicado a los niños hispanos, para que a través de su lectura, los pequeños aprendieran a ver (Martí, La Exposición de París).

Martí, al final del recorrido de su crónica, invitaba a sus pequeños lectores a "pensar”. El impacto de estos eventos en las sensibilidades colectivas actuaba en una doble dirección: cautivaba y alienaba al tiempo; instruía e in-formaba el deseo de posesión. En todo caso, este impacto sin duda podría ser considerado como el antecendente de esas futuras comunidades imaginadas de consumidores (García Canclini).

La puerta abierta que Martí dejaba para “pensar” sobre estos nuevos fenómenos de la cultura de masas, era quizás un llamado para re-pensar la agenda del intelectual dentro de las políticas culturales que traía la modernización; para ello sólo iluminaría algunos nudos soslayados por las élites letradas: la carga simbólica de la cultura material o el sentido social de las cosas (por ejemplo, ver la historia del hombre a través de sus casas); el peso cultural de la producción material y tecnológica (ver la sala de máquinas, el palacio de Artes Liberales, los muebles, la locería, subirse a la Torre Eiffel, a los globos aerostáticos); la constatación de un nuevo sujeto moderno multitudinario consumidor de cultura (las Exposiciones permitían calibrar ese "gentío”, “de cien mil visitantes”, que "como abejas", “como gusanos" “andan asombrados”); la capacidad ilimitada de interpelación de las modalidades de las culturas visuales y, en este sentido, el carácter restringido y disfuncional de la cultura letrada para llevar a cabo la modernización en América Latina (Martí, La Exposición de París). 
Es notable que, aunque el cubano se afiliaba a los circuitos letrados, no sólo no dejaba de inscribirse en la cultura de masas, sino que no la valoraba negativamente como tampoco la consideraba un factor de alienación -como sí sucedería con la Escuela de Frankfurt-. Martí empezaría por deconstruir y descolonizar este esquema. Curiosamente, su atracción particular por la electricidad y la luz, como su entusiasmo por las vistas desde puntos elevados (los globos y la Torre Eiffel), tenían que ver, por un lado, con su necesidad más democrática por reestablecer perspectivas más totalizantes e incluyentes (quizás reestablecer una visión más transparente). Y, por el otro, también tenían que ver con una crisis epistemológica más general del campo de visibilidad, crisis de paso de la concepción cartesiana y monocular de la visión (Jay), que afectaba el horizonte del intelectual tradicional que, en su miopía, borraba sujetos y prácticas culturales no inscritos en la letra. Entonces, dentro de esta lógica, no sólo tenía más confianza, al menos para el gran público, en la cultura de la mirada (la luz que se necesitaría para ver mejor), sino que también apostaba a una nueva estética de lo real, estrechamente vinculada con las modalidades visuales de la cultura, las nuevas tecnologías, los espacios de exhibición, y el cambio de los regímenes escópicos (Fig. 1).

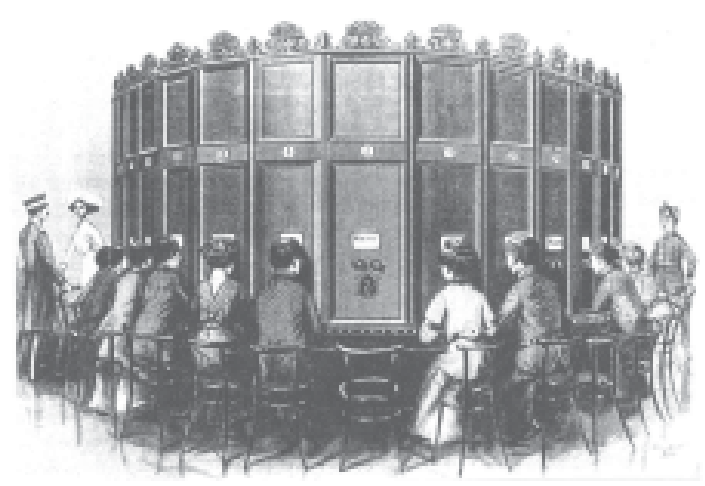

Fig. 1: Espectadores sentados ante lunetas para disfrutar del novedoso “Kaiserpanorama” (instalado en Berlín en 1883). Las revoluciones tecnológicas como el incremento de teorizaciones sobre la percepción, la anatomía ocular, la luz y la representación de lo real, configuraron un tramado que decidió la dominancia de estéticas hiperrealistas como expresión de la modernidad.

No en balde Martí aprovechó oportunamente las novedades tecnológicas de la imprenta para ilustrar abundantemente con grabados y fotografías La Edad de Oro. Ya se leía hacía rato a partir de la imagen, y no sólo en los medios impresos que fueron incorporando crecientemente ilustraciones, y, en particular, anuncios publicitarios cada 
vez más apoyados en el código visual. En este sentido, el tramado de esta tradición durante el xix podía yuxtaponer y mezclar tanto manifestaciones que iban desde los cuadros vivos, dramatizaciones, apoteosis, procesiones, carnavales, inauguración de monumentos; en otro orden, lecturas oralizadas, recitativos, veladas, tertulias, teatros, zarzuelas, óperas; hasta las más variados formatos en que circulaba la imagen, desde impresos de todo tipo (periódicos, pasquines y hojas sueltas), hasta fotos de familia, álbumes, tarjetas de visita, avisos publicitarios, artículos de consumo decorados con etiquetas ilustradas en miniatura (Hamon, Gruzinski, Martín Barbero).

Bajo la afición escópica, de por sí característica del ocularocentrismo de la Modernidad occidental, gravitaban algunos problemas de fondo, enfatizados a partir de la Ilustración y que durante el siglo XIX ocuparían gran parte de los escenarios de la producción teórica, científica, tecnológica, artística e inclusive las nuevas manifestaciones de la cultura visual de entretenimiento (Foster, Crary, Debord, D’Arcy Wood). Se podrían resumir del siguiente modo:

Uno: el principio de la mímesis, estrechamente vinculado al problema de la representación; más puntualmente, a la compulsión por re-presentar, por volver a producir con exactitud un simulacro de lo real, producir los efectos de una duplicación (fac-similar). En este sentido, la trayectoria de inventos y artefactos desde el Renacimiento es abrumadora. Desde la invención de la perspectiva, la cámara oscura, el eidophusikon, el caleidoscopio, el estereoscopio, el penakistiscopio, el telescopio, el microscopio, hasta los dioramas, los panoramas, cicloramas, pleoramas, cosmoramas, el daguerrotipo, la fotografía, y, finalmente, el fotorama y el cine. Del mismo modo y en esta misma línea, se inscribían los primeros museos y las grandes Exposiciones, que eran espacios performativos de la mirada. Ya en los tiempos de José Martí todas estas tecnologías habían adquirido tal desarrollo que permitían invertir la ecuación que iba de lo imaginado a su concreción material:

¡A ver quién imagina algo que no se haya visto jamás, y que no se pueda volver a ver! ¡Pues yo imagino, dice uno, hacer un cielo sobre la exposición, de luces eléctricas, de modo que se vean, como están en el cielo, todos los astros de la bóveda! ¡Yo imagino, dice otro, una flotilla de palacios (...) como las mansiones bizantinas, y todo fabricado sobre el río y ligado con calzadas, como las ciudades lacustres! (Martí, “En los Estados Unidos”, XII: 319)

Particularmente las Exposiciones eran los espacios idóneos donde los límites entre lo real y la ficción se hacían más porosos, porque eran espectáculos donde precisamente cosas y paisajes imaginados, leídos, referidos o soñados eran puestos a la vista y cobraban corporeidad. ${ }^{1}$

${ }^{1}$ Eduardo Blanco fue uno de los escritores más leídos en su época como después. Se podría decir que constituyó la primera vedette artística, y Venezuela heroica el primer best seller de la literatura nacional. Este texto se leía por entregas desde el periódico La Tertulia, donde periódicamente Blanco, por demadas del público, iba agregando cuadros de batallas. En 1881 recopiló estos capítulos para sacar la primera edición. Fue tan afamado, que sacó una segunda ampliada para el Centenario. La lectura fue organizando y preparando el ojo para hacer visible las imágenes que sugerían las letras. 
Dos: el carácter ocularocéntrico de Occidente, si bien llevaba implícita una vocación “pan-óptica” del ojo que veía-recordemos el proyecto carcelario de Jeremías Bentham de 1791- y una perspectiva monocular derivada del racionalismo cartesiano que había impuesto una micropolítica punitiva e imperializante de la mirada (Foucault, Vigilar y castigar; Crary, Techniques; Oettermann), después de la crisis del orden monárquico y el advenimiento de la República, otros dispositivos del ver se abrían paso, disputándose la hegemonía del observatorio censor. Sin que el régimen escópico de naturaleza panóptica perdiese terreno -sabemos que en el XIx fue el modelo más caro para llevar a cabo el disciplinamiento de la sociedad industrial-, coexistieron otras modalidades escópicas también deudoras de la modernidad, que desmontaban la visión monocular, abstracta y universalizante del sujeto cartesiano. Una tradición menos ligada a la rigidez geometrizante, y más ganada a un multifocalismo que le permitía priorizar un acercamiento descriptivo de un universo de cosas, y celebrar la sensualidad visual de la proliferación sin preocuparse por la posición (inmóvil) de un solo punto de vista.

Esta tradición es la que proporcionó las bases para la “sociedad del espectáculo”. A pesar de introducir una mirada multifocal y, por ende, más democrática, no desdecía el principio de la producción material de la sociedad capitalista. Su mayor apego a lo visual, su carácter más detenido en la descripción de los objetos (el microscopio y los binoculares son artefactos adscritos a este régimen), la acercaba más a la cultura de la imagen del XIX. Tanto el modelo panóptico como el panorámico tuvieron sus campos de incidencia, y cada uno desarrolló sus propios dispositivos culturales (Foucault; Debord).

Sin embargo, José Martí estuvo sensible y políticamente más ganado por la gramática pedagógica (más flexible, menos aherrojada de la tradición anti-cartesiana) que se desplegaba en las Exposiciones. El poder recorrer las galerías sin plan premeditado derivar de acuerdo con el llamado de los sentidos-, y ver sin la mediación del "ojo maestro”, se tornaba en una experiencia individual que validaba más democráticamente las subjetividades de todos (Comment). Recordemos de nuevo sus palabras: "Ningún libro ni ninguna colección de libros puede enseñar a los maestros de agricultura lo que verán por sus propios ojos” (Martí, “Nuestra América”, VIII: 368).

Tres: en estos escenarios el ojo del sujeto ejercitaba no sólo puntos de vista móviles y desjerarquizantes -recordemos que Martí invitaba a todos a subirse a la Torre Eiffel o a los globos aerostáticos para tener un panorama de París y experimentar la infinitud del horizonte-, sino también, a partir de las mil cosas exhibidas de cualquier parte del mundo, desarrollar una visión “planetaria” (Fig. 2).

En este renglón, las Exposiciones eran mapas mundiales que recomponían el imaginario de geografías locales resituándolas en una perspectiva mundializada.

Si bien las Exposiciones eran lugares festivos del capitalismo metropolitano y gestos simbólicos de la voluntad imperial, la mirada martiana descolocaba la predominancia occidental, incluyendo en su recorrido ocular las regiones de África, Asia y América Latina: “de paso veremos el pabellón de la República del África del Sur (...) la pagoda de Cambodia (..) el palacio de Anam (...) las arquerías de Argel (...) el pabellón de Venezuela, Nicaragua, Salvador, Guatemala” (Martí, La Exposición de París 26-34). La visión panorámica no necesariamente unidimensionalizaba las diferencias geo-políticas; quizás Martí ejercitaba una novedosa comprensión globalizada de la mirada des-exotizando y 


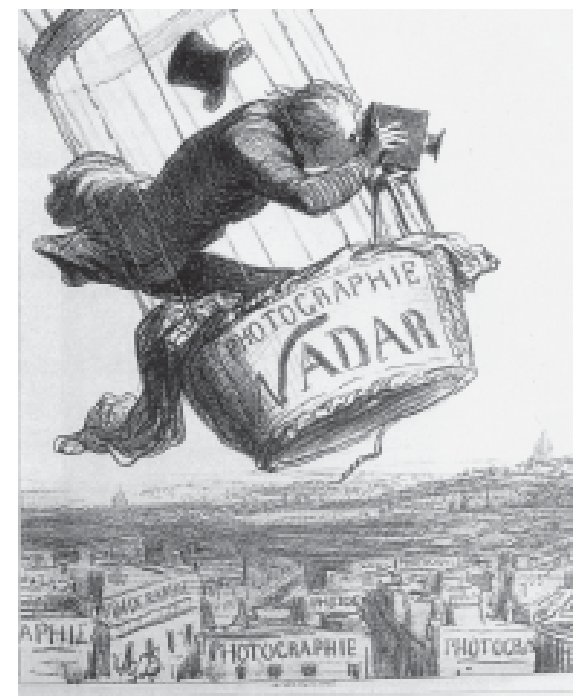

Fig. 2: El primer vuelo en globo se realizó 6 años antes de la Revolución Francesa. Desde aquel momento, no sólo constituyó uno de los eventos más sensacionales y celebrados del gran público, sino también pasó a convertirse en un símbolo político de las demandas y aspiraciones de las clases medias. El viaje en globo era una especie de "grand tour" que recomponía el mapa, porque desde una altura dominante el ojo descubría los límites de una ciudad que ya empezaba a desconocer. Aquí, "Nadar eleva la fotografía a la altura del arte” (1862), grabado de Honoré Daumier. des-alterizando las zonas "periféricas", recolocándolas como regiones igualmente implicadas en un proceso asimétrico de modernización.

Cuatro: en las Exposiciones regían las reglas de los centros metropolitanos, y con edulcoraciones y políticas exotizantes se reproducían las asimetrías de la modernidad. Al tiempo de ser intensos escenarios hedonistas para el regodeo y educación de la vista, José Martí advertía que eran así mismo lugares cruciales de una nueva fase de la economía mercantil, donde a partir del arte de la exhibición se vendía. Decía a propósito de la Exposición de Nueva Orleans (1883) que "es una Exposición de frutos primos (...) De frutos como los nuestros (...) Y en esto, si nos damos maña para presentar con garbo todo lo que tenemos, de fijo que no hemos de quedar a la zaga de nadie” (Martí, "Nuestra América”, VIII: 365, énfasis nuestro).

Establecía una nueva ecuación igualmente pragmática entre el aprender a ver y aprender a ser visto (que llevaba a ex-ponerse, a colocarse de tal modo para el consumo de los otros); era tomar conciencia -seguramente derivada de la experiencia norteamericana de moverse entre multitudes- de la doble direccionalidad de la mirada: ver y ser visto. La "maña” era aprovechar esa nueva economía política de los espacios escópicos para presentar de modo atractivo (“con garbo") los productos. Se trataba de "posar”, de fabricar identidades sobre la apariencia ("presentar para”), pero para entrar "sin quedar a la zaga de nadie” en el mercado internacional. Por consiguiente, Martí daba un paso más al no quedarse simplemente en un nivel contemplativo de las nuevas estéticas visuales, y calibrar la oportuna rentabilidad entre la erotización política de los sentidos y sus fines pragmáticos.

Lo que sobraba en América Latina era la cultura retórica; Martí deseaba que nuestros países concurriesen a las Exposiciones, pero como “pueblos fuertes”. Identificaba el ver no sólo con el aprender, sino con el comercio, y con particular énfasis en una economía de exportación. Colocar la producción “dura” (materias primas e incipientes industrias) en el horizonte visual del mundo para "que nos vean en trabajos viriles (...) Necesitamos inspirar respeto, necesitamos indicar por la fama de nuestras Exposiciones lo que hemos perdido en la fama de nuestras revoluciones (...) Necesitamos presentarnos como pueblo fuerte, trabajador, inteligente” (Martí, “Nuestra América, VIII: 363-64). 
Crear el homo economicus de las sociedades industriales, pero también de culturas cada vez más urbanas, masivas, donde la circulación de los lenguajes simbólicos debía ser eficiente y útil para una información a gran escala.

\section{Políticas de la cultura Visual}

José Martí no tuvo la oportunidad de ver con sus propios ojos la Exposición Nacional que el gobierno de Antonio Guzmán Blanco organizara en 1883 en Caracas para conmemorar el Centenario del Natalicio de Simón Bolívar. Sin embargo, desde las páginas de La Opinión Nacional los venezolanos mantenían con el cubano una estrecha relación a través de la lectura de sus crónicas, donde probablemente encontraron insumos acerca de las ventajas de efectuar Exposiciones en los propios países, más si podían atraer los intereses de los centros metropolitanos, más si podían ser lugares de intensa condensación de identidades modernas, más si podían presentar las novedades tecnológicas ante un público que sólo las había apreciado en revistas. Particularmente, la sociedad caraqueña era muy afecta al consumo de modas y bienes noratlánticos ya desde las primeras décadas de la República, tendencia que se profundizaría en los largos años del guzmanato (de 1870 hasta 1888). Por consiguiente, leía con no poca avidez aquellas crónicas de Martí que desde los Estados Unidos daban cuenta de los más recientes hallazgos del progreso material, y entendía que el lugar de las Exposiciones privilegiaba no sólo la vanguardia de los lenguajes de la modernidad, sino permitía la difusión de las tendencias hegemónicas de la cultura.

En su corta estadía en Venezuela (entre 1875 y 1877), Martí llegó a calar con perspicacia en un curioso proceso de modernización que se daba en la sociedad caraqueña: la apreciaba semipatriarcal y semiparisiense a la vez. Aquella sociedad soñaba con recrear para sí un "petit Crystal Palace"”2 para culminar, por una parte, con una densa trayectoria de vistosos espectáculos que el guzmanato había acuñado como estrategia de consolidación estatal, y que ya habían disciplinado las sensibilidades a las lógicas de la escena grandilocuente y al carácter coreográfico de los eventos públicos; aprovechar la Exposición para clasificar y tabular el patrimonio de recursos naturales y humanos del país para insertarse en mejores condiciones en el mercado internacional, haciendo también más atractivas la inmigración e inversión de capitales; y, finalmente, por otra parte, como estrategia dentro de las políticas simbólicas, cambiar la imagen de país selvático -que

\footnotetext{
2 Ciertamente el Centenario en 1883 promovió la producción historiográfica. Sin embargo, tuvo antecedentes que abonaron el terreno: el trabajo de José A. Pérez Literatura patria (1864); Juan Vicente González con su Revista Literaria (1865); el volumen de José María Rojas Biblioteca de Escritores Venezolanos Contemporáneos (1875); Juan Piñango Ordóñez publicó un ensayo "Literatura patria" (1875) en La Tertulia; los Perfiles venezolanos (1881) de Felipe Tejera; Literatura Venezolana (1883) de José Guel y Mercader; también Literatura venezolana (1883) de D. Ramón Hernández; Julio Calcaño en 1888 su Reseña histórica de la Literatura Venezolana; el Parnaso Venezolano (1892) de Julio Calcaño; en 1895 el Primer Libro Venezolano de Literatura, Ciencias y Bellas Artes; “La literatura venezolana” (1904) de José Gil Fortoul; y finalmente en 1906 La Literatura Venezolana en el Siglo xIx de Gonzalo Picón Febres.
} 
viajeros extranjeros habían forjado de Venezuela en sus relatos y grabados- por un país civilizado, al menos en su fachada.

Y es que a la fecha los venezolanos no andaban muy cómodos con la imagen de país “crudo” y virgen que desde los días de Alejandro von Humboldt se había acuñado a nivel internacional. Insistentemente las crónicas de posteriores viajeros fueron elaborando una Venezuela preferentemente deshabitada y salvaje. Al carecer de un denso sustrato de culturas indígenas, es decir, de "ruinas" de "antiguas civilizaciones", fue asimilada al modelo de las regiones sin historicidad pero llenas de recursos naturales. Interesaba más a la imaginación europea proyectar sobre sus territorios las fantasías del "continente vacío” con el consiguiente acicate de ocuparlo; y, por otro lado, complejos deseos eróticos y de afirmación viril que llevaban a repoblar (¿ficcionalmente?) al país de indios caníbales que, en su agresiva desnudez, sacrificaban a hombres blancos.

Ante la complejidad histórica que había acumulado Venezuela al haber sido cuna del pensamiento anticolonialista y revolucionario y escenario principal de las guerras independentistas, resultaba casi ofensivo para la élite criolla aparecer sólo como país de naturaleza exhuberante, mosquitos, caimanes, dantas, negros con torsos hercúleos, nativas cual odaliscas, pequeños grupos humanos ociosos... Ese era el saldo de Venezuela en el imaginario europeo a la hora de las grandes Exposiciones Universales.

Una Exposición, como las realizadas en Santiago de Chile (1875) y Buenos Aires (1882) podría desmentir contundentemente estas representaciones, y mostrar cómo Caracas, puerto de entrada a la América del Sur, reunía los suficientes hoteles, plazas, fuentes, bulévares, cafés, teatros, hipódromos, estatuas, y hasta arcos de triunfo, para que cualquier vecino se sintiese en casa. Sin descontar que un evento de esta magnitud terminaría por consolidar el aparato estatal venezolano en una doble dirección: internamente, viabilizaría una mayor articulación de las regiones alrededor de un centro imantador de sentido, que sería la producción del patrimonio nacional capitalizando recursos que configurarían el archivo consagrado del país; y, externamente, era poner en circulación una imagen más mercadeable de la identidad nacional. Después de todo, ya lo sabemos hoy -pero también lo sabía el General Guzmán Blanco- que la nación era una narrativa, era un performance. Era canalizar toda la utilería disponible para crear los efectos de una nación. Además eran los tiempos de fabricación de nacionalismos, y las Exposiciones eran esas ferias ideales donde la razón del progreso hacía competir vertiginosa y desigualmente a las naciones convertidas en sus propios fetiches (Benedict, Dosio).

Entonces, la efeméride del Natalicio del Libertador fue una coyuntura altamente favorable para poner en escena -a la vista de locales y foráneos- el espectáculo de una nación ordenada de acuerdo a las exigencias de la Modernidad: gozaba de infraestructuras, de intensa y sofisticada vida social, amén de tener una memorable historiografía desconocida. Fue el momento culminante en que convergieron orquestadamente una diversidad de narrativas -literarias, plásticas, arquitectónicas, visuales y letradas- que, alrededor de la figura emblemática de Simón Bolívar, configuraron el rostro de una cultura hegemónica de larga duración, al tiempo de satisfacer las expectativas y ansiedades del colectivo al reemplazar las memorias fragmentadas y dispersas por una sola historia contundente y mitologizada (Silva Beauregard). 


\section{Una fachada gótica}

El 2 de agosto de 1883, bajo las solemnes notas del himno nacional y un torrencial aguacero, se inauguraba la primera Exposición Nacional del país, y la tercera del continente latinoamericano. Se abría el Palacio de la Exposición ante una concurrencia poco usual de una Caracas de apenas 50.000 habitantes, pero con un cuerpo diplomático de todos los confines de la tierra. Venezuela se presentaba ante la comunidad internacional con un estilo "probado”: un edificio gótico no sólo acompasaba la tendencia arquitectónica de las grandes Exposiciones, sino que refrendaba las orientaciones políticas en materia de estilos de los centros del poder metropolitano (Fig. 3).

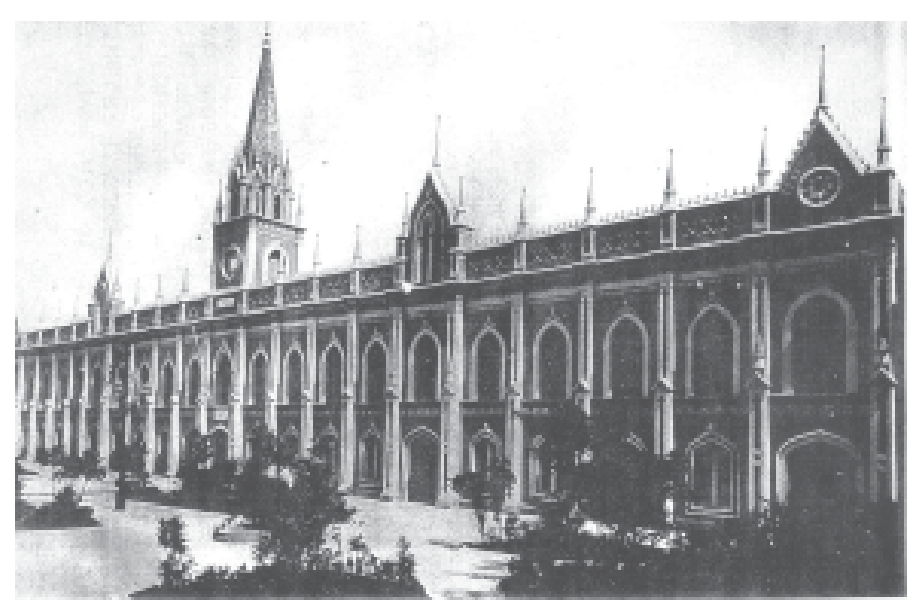

Fig. 3: Los arquitectos e ingenieros Juan Hurtado Manrique y Jesús Muñoz Tébar aprovecharon las antiguas estructuras coloniales del templo de San Francisco para transformarlas en las ojivas que configurarían el Palacio de la Exposición Nacional. El estilo neogótico sirvió políticamente a la élite criolla para blanquear en lo posible las aspiraciones cosmopolitas de un país “café con leche”.

El Palacio, con sus profusas ojivas cuyos vitrales dejaban colar la luz cromática sobre las galerías repletas de cosas; con sus patios y corredores que adecuaban jerárquicamente el patrimonio; con su torre almenada que permitía calibrar in extenso las transformaciones de la ciudad, se erigía frente al Capitolio Nacional. Una cátedra magistral nunca antes vista para una población mayoritariamente iletrada, pero habituada a los espectáculos públicos del guzmanato. Sólo que esta vez tendría que pagar para ver el universo de novedades, y pagar el doble para verlas de noche bajo la luz de 14 reflectores y 43 bombillas eléctricas. Se había construído un edificio -quizás el primer esbozo de centro comercial-para ver a modo de enciclopedia visual los bienes materiales del país (Gasparini y Posani). Un Palacio de alta concentración pedagógica: la historia nacional (pasada y presente) se fabricaba en forma esquemática y asequible -quizás era la primera simplificación "light" 
de la cultura- para que el gran público pudiese aprehender rápidamente una narrativa ejemplarizante y sin fisuras de la nación. Así, la fachada gótica ordenaba simbólica y políticamente el discurso material de la nación (Pomian, Karp y Lavine).

Si la Exposición era el libro visual que contenía a la nación, entonces ¿cómo leerlo? ¿Cuáles eran las claves de lectura que resituaban a Venezuela como país moderno, pacificado, y con posibilidades de inscribirse en la órbita del progreso?

Las emergentes capas medias -y la oligarquía guzmancista había salido de las últimas guerras civiles- aprendieron rápidamente que la política de las formas podía garantizar ascensos y distinciones sociales. Re-producción y mímesis eran dispositivos que permitían ubicarse en la escala social y ejercer un no despreciable poder de interpelación. El Palacio de la Exposición en su neogótico victoriano no sólo creaba una imagen “exportable” del país, rentable para la inversión/extracción, sino al reproducir los estilos metropolitanos creaba una plataforma para un diálogo centro-periferia menos desigual (Leprun). La selección y transculturación de lenguajes artísticos se inscribía en un complejo tramado de debates, y mucho tenía que ver con luchas por el poder interpretativo. Veamos:

Sin duda que el estilo Gótico creaba un rostro más “civilizado” del país; al menos desnaturalizaba las versiones imperiales invirtiendo algunas de sus premisas: no era de entrada una región desocializada; sino centro neurálgico de la historicidad moderna del continente. El peso de esa historicidad se expresó mediada por los estilos más prestigiados de los centros metropolitanos. De otro modo, se trocó el discurso que nacionalizaba la naturaleza -que ligaba la representación de la nación a los elementos naturales convertidos en mercancías-, por el discurso que nacionalizaba la historia-que ligaba la representación de la nación a los héroes convertidos en mitos y mercancías-. Si Venezuela era identificada con oro, diamantes, petróleo, café, cacao, debía ser desde aquel momento identificada con la patria de Simón Bolívar.

Había pues que producir suficientes narrativas con efectos historizantes, es decir, una máquina de dispositivos para crear pasados y genealogías de todo tipo. La compulsión genealógica era doble: por un lado, para contrarrestar el impacto de diversas modernidades había que crear tradiciones; y, por el otro, debían ser en este caso de prestigio. La adopción del gótico victoriano -que recordaba antiguos tiempos medievales, caballerescos y señoriales- se avenía sin disonancias al aire napoleónico que revestían los héroes y el mismo Antonio Guzmán Blanco. Se cuidó mucho en aristocratizar esas genealogías y acercarlas lo más posible a los estilos noratlánticos. Parecía así tener la nación venezolana un origen de larga data, raíces que se hundían en una antigüedad obviamente imaginada, construída como el escenario de un teatro (Almandoz Marte). Pero el efecto de pasado era nuevamente modificado: se trocaba el pasado colonial hispánico por la ficción de un “medioevo" inglés, con lo cual los procesos de europeización ocultaban complejas operaciones de blanqueamiento, que la ascendencia hispana no sólo no resolvía sino que complicaba. Recordemos que después de la Independencia la relación con el Hispanismo era reñida.

Sin duda la impronta estilizada del gótico blanqueaba. Probablemente varios fantasmas atormentaban el inconsciente de estas nuevas élites: uno de ellos, tenía que ver con la limpieza racial, parecer lo menos posible "gente de color", colocarse máscaras blancas sobre pieles mestizas. El otro de ellos, tenía que ver con la discontinuidad del grupo social 
tradicionalmente hegemónico; es decir, el reemplazo de los criollos blancos de la colonia que encabezaron la Independencia (los Bolívar, por ejemplo), por nuevos sectores de origen popular, que fueron ascendiendo en el escenario político a raíz de las guerras Emancipadora y Federal (los Páez y Guzmanes, por ejemplo) (Díaz Sanchez 1950).

La hipertrofia guzmancista en importar estilos modernos eran máscaras que escondían complejas intrahistorias nacionales. El Gótico en este sentido fue una de las modalidades más cosmopolitas para situarse en el centro de la occidentalidad blanca, al tiempo que reinscribía a Simón Bolívar en otra línea de prestigio: lo convertía en un lord inglés o en un caballero de la mesa redonda: servía de bisagra emblemática para articular la vieja élite patricia con la nueva oligarquía del dinero. Su origen vasco tendía más fácilmente un puente entre las naciones de la revolución industrial y la nación mestiza. El sustrato hispánico no se descartaba; se retrabajaba: de algún modo servía como nexo (por la sangre, por la lengua) para reestablecer la conexión con Europa.

Sin embargo, la elección de un Palacio gótico en plena zona tórrida se inscribía también en otra agenda más ligada a las políticas de las formas y de los estilos arquitectónicos a la hora de la distribución de las representaciones identitarias de los países latinoamericanos en las Exposiciones Universales. El poder de las formas (o fachadas) decidía la circulación de las naciones en una economía ya mundializada. Las formas arquitectónicas simbolizaban la hegemonía o subalternización de los poderes en pugna, estilos imperiales o los colonizados.

Por consiguiente, el Gótico se emparentaba con el "high style” de Inglaterra principalmente, que había considerado reestablecer entre 1830 y 1860 un estilo más cristiano y occidental para contrarrestar las modas bizantinas y orientalizantes que habían ganado los gustos a raíz de las conquistas de Turquía y Oriente por parte del imperio inglés. Pero también se sumaban a estas modas, la egiptomanía que se disparó por toda Europa después de las campañas militares de Napoleón (D’Arcy Wood). De este modo, México comenzó a circular en el imaginario europeo ligado, primero, a las ruinas aztecas, y, segundo, emparentado al arte egipcio. Esta identificación que “orientalizaba” a México al tiempo de "aztequizarlo", se mantuvo hasta las Exposiciones de Nueva Orleans (1884), donde tenía un "Palacio de la Alhambra”, y en la de París (1889), donde fue memorable por su "Palacio Azteca" (Tenorio Trillo).

En este contexto, los arquitectos ingleses -especialmente los que integraban la Ecclesiological Society, entre ellos su fundador Beresford Hope- vieron amenazado la respetabilidad del poder inglés, más cuando hasta los edificios oficiales habían adoptado también la manera bizantina. Consideraron que las formas orientalizantes en arquitectura no constituían un verdadero estilo; rezumaban aires semiprimitivos que recordaban las tribus nómadas del desierto; y, por ende, Inglaterra, si quería erigirse en capital de la modernidad imperial occidental, debía caracterizarse por imponer sus propias formas, y éstas eran las de la ecumene cristiana. Por consiguiente, el renacimiento del Gótico en el XIX tuvo un sentido profundamente moderno, porque ligaba los centros de la revolución industrial y tecnológica a sus propias tradiciones cristianas (Crinson). Y, significaba, por tanto, su adopción del deseo de pertenencia a la órbita de la comunidad cristiana. Por el otro lado, en la trayectoria de las Exposiciones Universales, los países latinoamericanos, como el caso de México que hemos visto, cargaban con el estigma de esa orientalización. 
Si los pabellones mexicano y chileno se habían presentado bajo el estilo morisco, y otra vez en estilo egipcio, Venezuela probablemente no quería identificarse con esas políticas exotizantes. Ya tenía a sus espaldas el peso de un exotismo que ni siquiera pasaba por la orientalización. La cuestión era inscribirse lo más ortodoxamente posible dentro de las fronteras estilísticas que demarcaban los límites de la civilización europea. Tal vez así con la adopción del Gótico se podía atraer por mimetismo los bienes del progreso del norte. Además, el Neogótico podía esconder con sus aires feudales la sobrevivencia en los trópicos de una mano de obra semiesclava/semifeudal de alta rentabilidad para el capital foráneo. En cierto modo, la elegancia señorial borraba el país indígena y mestizo, porque al blanquear la fachada reintroducía subliminalmente las jerarquías de una sociedad poco democrática.

No dejaba de reproducir las contradicciones de la modernización. El Palacio gótico era una caja de promesas: como una catedral, sacralizaba las riquezas naturales del país y oscurecía la enajenación de las mercancías; como una fábrica, apostaba a la nueva economía-mundo aportando un cuerpo laboral despolitizado porque no había conocido la explotación industrial.

\section{Vista desde la torre}

El numeroso público que concurrió en los 15 días que duró la Exposición Nacional, pudo disfrutar de una nueva experiencia visual: subirse a la torre almenada que coronaba el pórtico principal del edificio. En una ciudad que aún conservaba los aires coloniales -a pesar de los enormes esfuerzos del guzmanato por modernizarla-, no abundaban las edificaciones altas, como tampoco hasta la fecha se conocían los viajes en globo u otros entretenimientos -por decir, las rotondas circulares con panoramas o dioramas- que hubiesen permitido ordenar la experiencia visual de los caraqueños como producto de los artificios tecnológicos. Caracas estaba lejos de ser esa París soñada; tampoco alcanzaba las dimensiones de otras ciudades latinoamericanas.

Sin embargo, había mucho que descubrir con la mirada (Fig. 4). La torre no dejaba de ser una novedad, más si se podía ver por primera vez desde un punto elevado toda la ciudad, y constatar en una visión de conjunto -panorámica- los descollantes edificios (el Capitolio,

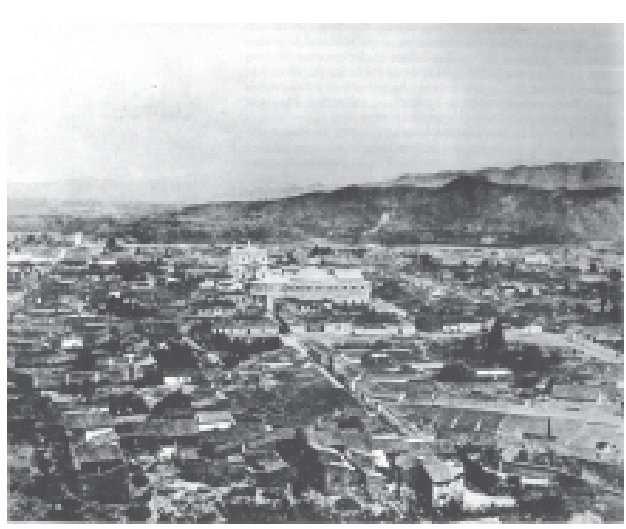

Fig. 4: Vista panorámica de Caracas, cerca de 1890. En el transcurso del siglo el daguerrotipo cautivó las sensibilidades por el retrato y por la fotografía de paisajes. La Exposición Nacional también pudo ofrecer a su público vistas de una ciudad que se expandía. Al fondo el "Teatro Guzmán Blanco”y la Basílica de Santa Ana. Estas tomas favorecían desde “arriba” los alcances del progreso... 
el “Teatro Guzmán Blanco”, el Panteón, la Basílica de Santa Ana, el Templo Masónico, el Hospital de Lázaros, la Clínica del doctor Aguerrevere, el "Hotel de France”, la “Camisería de Fermín Cubría”, la "Fábrica de Espejos” de Nemesio Herrera, el gran almacén de modas "Palacio de Cristal", el restaurant "Louvre"), los monumentos (las estatuas "El Saludante” y “Manganzón” destinadas a Guzmán Blanco, las escuestres de Simón Bolívar, el Arco de la Federación), plazas y avenidas (el Boulevard del Capitolio, la Alameda del Panteón, la Plaza Bolívar, la Plaza de Abril).

Después del terremoto de 1812, los caraqueños se habituaron a caminar entre escombros y edificios agrietados, calles enlodadas, y casas arruinadas. En los 13 años que llevaba el guzmanato, la ciudad fue higienizada y embellecida, sin descontar la considerable inmigración que aceleró los índices demográficos. Todos estos movimientos y transformaciones se habían vivido desde "abajo", desde la calle, pero no desde "arriba”. Ahora la torre permitía reconvertir la vivencia que los ciudadanos habían tenido como actores “dentro" del escenario, en una experiencia que los distanciaba de sí mismos en un "afuera”, invitándolos a flaneuar sobre un nuevo paisaje: los transformaba en espectadores del paisaje urbano. El cambio de punto de vista modificaba la perspectiva. Ahora era la ciudad allí abajo quien se convertía en protagonista, en el gran personaje de los tiempos modernos, minimizando, por otro lado, el protagonismo del individuo y su nueva autopercepción más diluída entre la muchedumbre. ${ }^{3}$

La vista ampliaba el horizonte permitiendo recuperar -sólo con el ojo- los bordes de la ciudad y sus fronteras con la vida rural. Además, la percepción de la ciudad en sus 360 grados ofrecía al vivo el espectáculo de los panoramas, que los venezolanos habían visto vicariamente a través de fotografías o que habían podido comprar en versiones reducidas en la esquina de Mercaderes. La vista debió ser “espectacular”, y sorprender a más de un conocedor mundano, porque hasta el mismo Adolfo Ernst tuvo la delicadeza de transcribir en su catálogo el mapa de la ciudad:

Preciosa es la vista que allí se presenta al espectador sobre todo el valle de Caracas: aparecen los jardines de la plaza Guzmán Blanco y del Capitolio (...) se extiende la capital con la red rectangular de sus calles, sus templos y monumentos notables; hacia el occidente se divisa la estación del ferrocarril de La Guaira (...) en dirección suroeste se pierde la vista en las fértiles campiñas del Guaire hasta Antímano (...) al sur las colinas del Valle, en cuyas faldas se distingue el ferrocarril del Centro; hacia el oriente abarca la mirada una vasta extensión de verdes sementeras (...) y surge la iglesia de Petare en las ligeras brumas del lejano horizonte. (Ernst, I: 19-29)

\footnotetext{
${ }^{3}$ A partir de 1883 -salvo el caso de Los Mártires, 1842, de Fermín Toro- comenzaron a escribirse novelas que exploraron el espacio urbano. Se inscribieron en el Modernismo literario y sus epígonos. Casi todas hicieron reflexiones mordaces sobre Caracas y sus habitantes: Julián (1888) de José Gil Fortoul; Felipépolis (1889) Santiago Pérez Gil; Los abismos de Caracas (1894) de Eduardo O’Brien; Todo un pueblo (1899) de Miguel Eduardo Pardo; Idolos rotos (1901) de Manuel Díaz Rodríguez; El hombe de hierro (1907) de Rulfino Blanco Fombona; Villa sana (1914) de Carlos Elías Villanueva; Vida de Caracas (1919) de Emiliano Hernández; hasta Ifigenia (1924) de Teresa de la Parra.
} 
La visión empezaba a ejercitarse en “vastas extensiones”, lo que significaba incorporar la nueva sensación de infinito ("lejano horizonte”) que traía en vivo un nuevo mapa geográfico. La mirada panorámica coincidía con un ojo posesivo que seleccionaba en su mirar las tecnologías de la comunicación (ferrocarriles, barcos, carruajes, teléfonos, telégrafos) que viabilizarían una política de expansión y control para la extracción. Inscribía históricamente su mirada en la economía de una visión occidental. No es casual, por demás, que al interior del Palacio de la Exposición predominaron las máquinas para la industrialización (molinos, trillas, segadoras, motores hidráulicos, telares, lavadoras, prensas) y novedades en materia de comunicación (coches, rieles, vagones, embarcaciones, teléfonos, timbres eléctricos, máquinas electro-magnéticas), más que artefactos relacionados con los adelantos ópticos. El carácter difusionista de la modernidad entrañaba un movimiento expansivo: el descubrimiento del horizonte en el xvıI decidía las revoluciones comunicativas para alcanzarlo (Oetterman).

La vista de la ciudad desde la torre se duplicaría en el salón principal del Palacio: una vista panorámica también de Caracas decoraba uno de los muros de la sala. A pesar de ser un fresco, el público se podía entretener en las nuevas tecnologías de la duplicación, y hacer un seguimiento de los alcances verosímiles de las artes de la reproducción, y comparar el panorama antes visto con la pintura. Pero también comparar la modernidad de su capital con las fotografías de Londres que decoraban las galerías de la Exposición. De otro modo las invenciones ópticas se hacían presentes a través de las ficciones miméticas de lo real.

\section{El Salón Bolívar: el culto a las celebridades}

Al traspasar el pórtico principal, a mano izquierda, se abría el “Salón Bolívar”. Su paso era obligado. La curiosidad embargaba a la concurrencia. Se cumplían cien años del natalicio del Libertador. Su imagen tenía mil rostros: hasta el Ilustre Americano se le parecía. Eran semblanzas, copias, representaciones... Finalmente, se podía ver y palpar el cuerpo del héroe: mudas de ropa interior, hojilla de afeitar, jabonera, lociones, aguamanil, botas de campaña, zapatos, pantalones, camisas, caja de rapé, anillos, alfiler de corbata, medallas, casaca militar, sopera, cubiertos, platos, fragmentos de madera de la urna en que vinieron sus restos a Venezuela, la primera lápida de mármol, y con la ayuda del microscopio hasta una "concreción de fosfato de cal hallada por el doctor Révérend en el pulmón del Libertador” (Ernst, I: 691). Los ojos del público podían incursionar en las entrañas del Padre de la Patria, y, sin ningua retórica aparente, esos objetos íntimos hablaban por él. Producían un chocante efecto de inmediatez humana, de familiaridad, de cuerpo vivo y doloroso, de cercanía, precisamente de efecto "real”, con un poder de legibilidad que confería la materia visible

Simón Bolívar dejaba de parecer una invención del guzmanato; dejaba de ser tanto un monumento de bronce, una efigie hierática y distante, como un rostro y nombre que se había multiplicado en todos los registros de la vida cotidiana. Sacralizado y trivializado a la vez, inalcanzable pero maleable, su corporeidad “real” se escurría entre estos extremos sin lograr consolidar la trascendencia como eje imantador de memoria histórica y como ícono celebratorio del progreso nacional. La Exposición recapitulaba de una manera más 
eficiente y exitosa este “doble cuerpo del rey” (Kantorowicz, Richards), ordenando bajo su emblema tanto las narrativas de la alta cultura como las nuevas formas de la cultura de masas. En todo caso, su cuerpo ahora se des-doblaba tanto para el consumo de la oficialidad estatal, como para el consumo de la inmediatez cotidiana.

Aparte de las estatuas ecuestres, de los bustos en piedra, de las innumerables efemérides celebradas en su honor, la estampa de Bolívar había sido apropiada desde hacía varios años por el mundo de la publicidad: vinos, licores, perfumes, lencería, cojines, objetos artesanales, adornos, negocios, hoteles, llevaban su nombre. El almacén "Rojas Hermanos” vendía desde 1870 pisapapeles de cristal con las imágenes de los próceres; desde 1876 se pusieron de moda pañuelos con orlas verdes y azules con estampas de los monumentos del Libertador, el Capitolio, el Panteón; desde 1877 la heladería "El Polo Artico”, aparte de ofrecer helados, la esposa de Manuel María Zarzamendi atendía los encargos de su clientela con sus miniaturas de cromofotografía al óleo reproduciendo escenas con héroes nacionales...

Bolívar era un objeto de consumo, donde la dinámica comercial quería validar la mercancía en un doble valor: el de uso y el simbólico. Tan prestigioso ícono dotaba al producto de valor comercial y garantizaba su consumo; y, por el otro lado, el consumo de la mercancía bajo su rúbrica hacía circular y publicitar la imagen del héroe en un destello de historia nacional fácilmente consumible. Una extendida cultura que había masificado elementos de la historia oficial, y que en su reconversión kitsch garantizaba por partida doble una forma sustitutiva de recreación de la memoria colectiva, aparte de transformar la figura sacralizada en una celebridad del presente, en una especie de movie star o vedette que llenaba las fantasías colectivas.

Sin embargo, aquellas pertenencias del cuerpo real del Libertador operaban de un modo distinto a su habitual figuración. En cierta forma se alejaban tanto de la reificación mercantil como del exceso retórico de las festividades públicas, pero ingresaban en otro reino no menos desconcertante: su simple colocación allí producía el impacto deseado, el efecto de verosimilitud. Este nuevo realismo articulaba en su crudo despojamiento una presentación melodramática de las cosas -sólo imaginemos la impresión que debió causar esa piedra de cal de los pulmones tuberculosos del Libertador-. Es decir, la fuerza dramática que tenía el orden de las cosas para desplegar en su performance un conjunto de narrativas (in)visibles que debían configurar el nudo central del Centenario: hacer converger productivamente-es decir, con impacto doctrinario-la confianza en las nuevas tecnologías del progreso y el ordenamiento de la memoria histórica nacional.

Esos objetos de la intimidad de Bolívar decían de un cuerpo ausente; eran los "restos” de un pasado borrado, las "ruinas" de una historia desaparecida. Configuraban una "estética de la desaparición” que en su melodramática paradoja hacían aparecer otra cosa: elaboraban el cuerpo de la memoria, más que el cuerpo en sí (Virilio, Déotte). Dialécticamente eran los signos de un no ser (un tiempo imposible, un vacío); pero eran el lugar (el monumento) de la inscripción de la memoria como un constructo del presente (la recuperación del tiempo por la historiografía).

Y es que el "Salón Bolívar” ofrecía en su entera decoración una cómoda resolución para llenar la imaginación histórica. Frescos con las batallas de Carabobo, Boyacá y Junín ornamentaban las paredes. En el techo, la figura alegórica de Venezuela, representada por 
una especie de Atenea, descendía del cielo raso envuelta en la bandera tricolor (Ernst, I:21). Los vacíos de la sala así como los olvidos de la memoria se saturaban con un único acontecer contundente y redundante: escenas a todo color de las guerras independentistas (1811-1824). Los cuerpos viriles representados restituían de vida (ilusoria) a los “restos” de Bolívar, amortiguando las fisuras entre pasados y presentes, entre ruinas y monumentos. El poder de las imágenes sustituía otros actores heroicos más recientes y menos cómodos para la oficialidad, por unos protagonistas distantes que podían ser punto de convergencia para la elaboración de una historia nacional reconciliatoria. De este modo, los restos de una antigua catástrofe (las huellas del héroe) eran las pruebas de una "realidad" que colocaban la lectura de las imágenes dentro de una estética del documento y podían garantizar una interpelación convincente.

Ahora, esas siluetas de los frescos como los objetos del Libertador se reflejaban sobre la bruñida superficie de un enorme espejo de la companía “Joaquín é hijo” colocado en un ángulo del salón. Pero... ¡los espejos no eran una novedad!, lo que sí probablemente el efecto multiplicador de las imágenes refractadas que se re-producían en él. Establecía una oblicua coherencia con otra serie de artefactos expuestos en las galerías de la Exposición, que por su naturaleza respondían a esa cultura de la serialización. Tantas máquinas reunidas nunca vistas confirmaban otros registros de distinción de la producción cultural: de la existencia de un público masivo, de otras sensibilidades que no pasaban necesariamente por las "bellas artes y letras".

El espejo también hablaba en clave simbólica del reflejo de un rostro. Implicaba la elaboración de una apariencia para (ex)ponerse delante del espejo para mirarse y ser mirado. En la superficie del espejo se reflejaba una nación maquillada para su publicidad. Pero como todos los reflejos, la cámara oscura invertía la imagen proyectada: si bien en las Exposiciones Universales Venezuela entraba por el orden de sus materias primas, ahora ella se ordenaba a partir de sus productos procesados. La inversión devolvía el país salvaje y “crudo” acuñado en los espacios metropolitanos, en país civilizado y “cocido”. En el juego de espejos se negociaban apariencias: las materias primas -exhibidas en el fondo del Palacio- fueron recubiertas de historiografía. Y fueron precisamente estas ficciones historicistas las que transformaron el valor de uso de las riquezas naturales en valor de cambio. El oro, el caucho, el café, el cacao, el asfalto, las maderas, estaban siendo mediadas por el "Bolívar de plata” -unidad monetaria nacional apenas acuñada cuatro años antes del Centenario- que revertía la naturaleza en bienes de consumo. Así, la construcción del héroe nacional a través de las artes y letras sellaba el cuerpo de una nueva economía ahora basada en la capitalización del "Bolívar”.

\section{El diorama de la guerra}

Los artistas venezolanos apuraron sus óleos y esculturas para presentarlas en el “Salón de Bellas Artes” de la Exposición Nacional. La Exposición fue un gran laboratorio que conjugó las gramáticas de la tienda por departamentos, de la fábrica, del zoológico, y del museo. Era la primera vez que un evento lograba reunir una colección tan numerosa y variopinta de cuadros realizados por venezolanos y artistas extranjeros. Para la concurrencia se desplegaba un universo de formas y colores que, lejos de haber sido una 
experiencia “estética” de la alta cultura, concurría antes que nada a in-formar de vivas representaciones a una memoria deshilachada.

Poquísimos leían en el país (un 90\% era analfabeto); más en Caracas (el 50\% manejaba las letras). Por decir, no había bastado una década de fanática lectura oralizada de Venezuela heroica ${ }^{4}$ de Eduardo Blanco para que los venezolanos pudiesen imaginar las escenas leídas. $\mathrm{O}$, tal vez, la lectura de uno de los textos de mayor impacto, había creado un clima que exigía indirectamente al cuerpo de pintores la visualización urgente de lo que las letras reprimían. El Centenario coronaba el éxito de Eduardo Blanco con una segunda edición ampliada de esta obra. Sin duda que se había formado un público no precisamente elistesco que, imbuído o no en estas "letras heroicas", deseaba ahora ver el panorama de esa magna gesta. La Literatura era sólo un modesto abreboca de otras formas culturales de mayor alcance. Con ver se podía leer lo fundamental de la historia patria. La representación visual no sólo reproducía el gesto, sino indicaba su falacia: los caminos de la instrucción debían tomar otras estrategias más modernas y eficientes. Acreditaba el espacio de la Exposición con la visualización de la cultura como una práctica pedagógica de alta intensidad.

Por ello, la galería de óleos cumpliría en aquella oportunidad las veces de un arte de entretenimiento masivo; y lo que habría de ser luego patrimonio prestigiado de la nación, era en esos días un arte de consumo más popular. No en balde con los medios visuales se emprendía una cruzada también épica que demandaba la captura de la atención del público con fines proselitistas. Los óleos seguían siendo arte para un pequeño grupo de entendidos; pero para la mayoría un articifio de las modernas tecnologías del sensacionalismo realista (Oettermann, Comment). Muchas de las extensas telas hacían las veces de aquellos “panoramas” y “dioramas” de otros paisajes y guerras que los venezolanos habían podido adquirir en versiones miniaturizadas, y que ahora esas paredes desplegaban en tamaño natural.

La historia nacional se concentraba en una sola instantánea que se amplificaba y redundaba en detalles: el tiempo histórico se resumía en los años de la lucha emancipadora, y comenzaba con La Firma del Acta de la Independencia (el 5 de julio de 1811) (Fig. 5) de Martín Tovar y Tovar: la tela de siete metros de largo desplegaba un cuerpo de virilidades que decidía la independencia política de la nación, pero también en el presente decía del deseo de una sociedad exclusivamente masculina. Encerrados sobre sí mismos más bien firmaban un pacto de lealtades viriles, como acérrimos dueños de las academias, colegios, ateneos, museos y tertulias.

No es de extrañar que en este conexto falocrático las obras de las mujeres no tuvieran cabida en el salón de las “Bellas Artes”; se las concentró en espacios donde sólo exhibieron sus labores de mano, conservas, y adornos hechos con materiales perecederos. Sin

\footnotetext{
${ }^{4}$ Eduardo Blanco fue uno de los escritores más leídos en su época como después. Se podría decir que constituyó la primera vedette artística, y Venezuela heroica el primer best seller de la literatura nacional. Este texto se leía por entregas desde el periódico La Tertulia, donde periódicamente Blanco, por demandas del público, iba agregando cuadro de batallas. En 1881recopiló estos capítulos para sacar la primera edición. Fue tan afamado, que sacó una segunda edición ampliada para el Centenario. La lectura fue organizada y preparando el ojo para hacer visible las imágenes que sugerían las letras.
} 


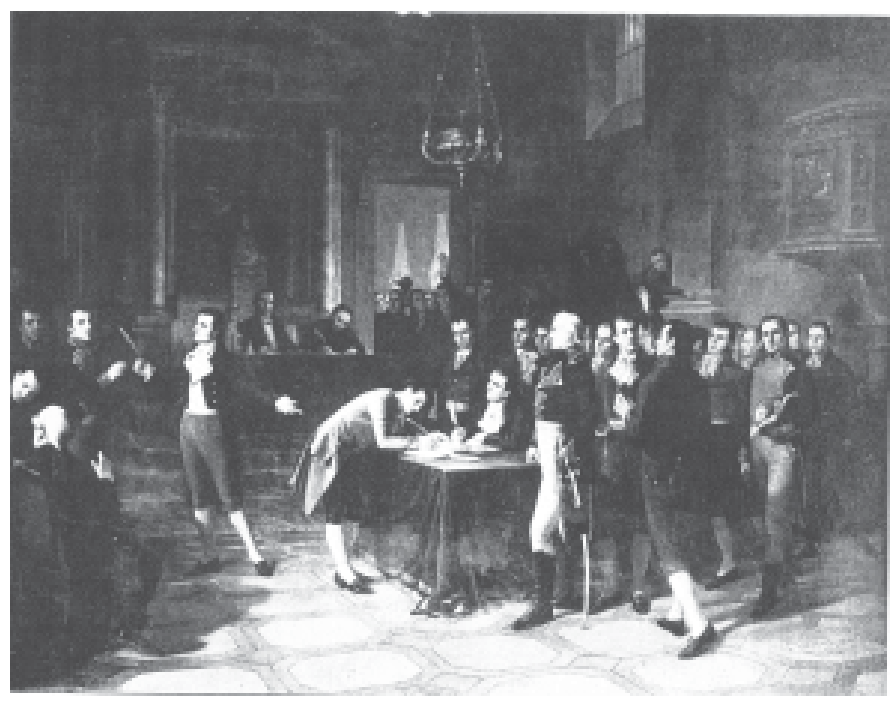

Fig. 5: "La Firma del Acta de la Independencia" recibió el premio principal de la Exposición. Por su enorme tamaño hacía casi las veces de un espectáculo panorámico del 5 de julio. La escena ganó las sensibilidades del gusto popular pasando a convertirse en motivo frecuente de cuadros vivos.

embargo, constituyeron un punto discreto de contra-memoria (Crary, "Spectacle, Attention...”; González-Stephan, “Con hilo y aguja...”). Los pintores que se aventuraron a representarlas para salpimentar la tónica épica dominante del salón, decapitaron sus cuerpos al llevar la Cabeza de una madona (de Antonio Herrera Toro) y la Cabeza de una anciana (de Martín Tovar y Tovar). En la sala donde ellas expusieron, expresaron de otro modo sus lealtades patrióticas: se suscribieron a sus propias memorias: sin palabras, bordaron la imagen de la costurera revolucionaria Policarpa Salavarrieta.

Sin embargo, la historia la hacían los hombres. El espectáculo panorámico de la guerra emergía con gran dramatismo: protagonistas, vestuarios, caballerías, campos de batalla y, sobre todo, acción. Todas aquellas imágenes estaban en movimiento: El Desembarco de Bolívar en Ocumare y La Batalla de Carabobo de Juan Antonio Michelena, Entrega de la bandera invencible de Numancia al Batallón sin nombre de Arturo Michelena, El combate en el lago de Maracaibo (de tres metros de largo) de José Manuel Maucó, La muerte de Girardot de Cristóbal Rojas, y Entrevista de Bolívar y Sucre en el desaguadero de los Andes de Manuel Otero, Fachada de la Casa Natal del Libertador de Néstor Hernández, La muerte del Libertador de Antonio Herrera Toro. La fuerza de las imágenes impregnaba las sensibilidades de ficciones heroicas, de atmósferas marciales, de virilidades superdotadas, que hallaron su paroxismo en el fresco que decoraba la cúpula del Salón Elíptico del Capitolio contiguo al Palacio de la Exposición (Fig. 6), que ilustraba otra vez la Batalla de Carabobo de Martín Tovar y Tovar, pero en una versión "panorámica”. 


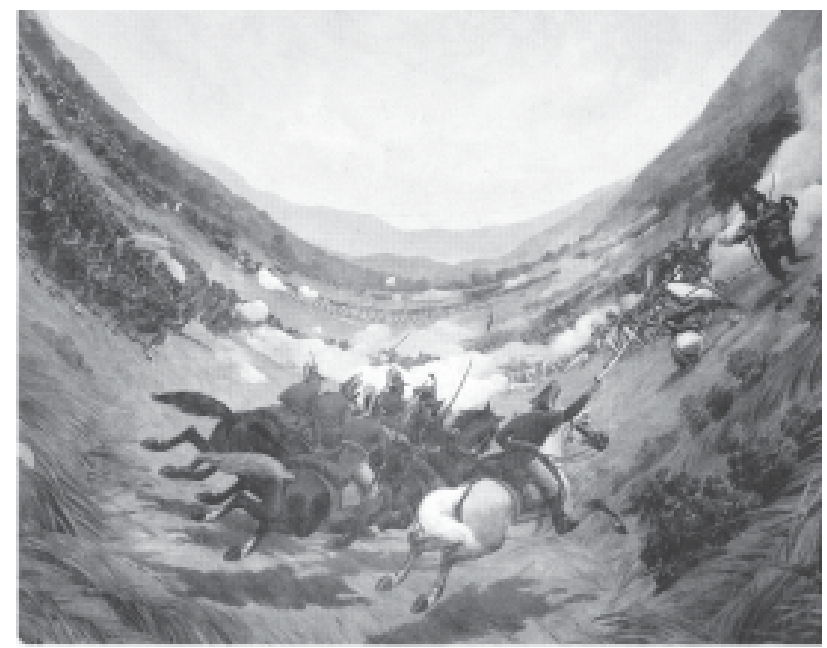

Fig. 6: La representación de la guerra sobre una superficie circular ofrecía al espectador no sólo puntos de vista policentrados, sino la liberación del marco restringido de la pintura de caballete. El hiperrealismo de las imágenes producía efectos empáticos. Estas imágenes dotaban a la ciudadanía venezolana de modernas representaciones de su historia, que permanecerán en el imaginario hasta finales del siglo xx.

El espacio circular de la cúpula hacía las veces de rotonda y creaba los efectos de una visión panorámica casi cinematográfica de las guerras de Independencia. Los venezolanos sabían de la existencia de estos entretenimientos en Europa que causaban una enorme sensación por los efectos de verosimilitud, que, gracias a las técnicas del detalle meticuloso, reproducían con precisión fotográfica extensas vistas de paisajes y, en particular, de batallas.

Algunos factores a lo largo del siglo condicionaron el desarrollo de formas culturales más proclives a las demandas del gran público: la revolución industrial y tecnológica, el crecimiento poblacional de las ciudades, la cada vez más intensa circulación de impresos, la avidez de las masas por saber más acerca de guerras en lejanas geografías que decidían el destino de las naciones. Preferentemente los panoramas circulares acercaban a los centros urbanos extensas vistas de otras ciudades del continente (Londres, París, Edimburgo, Florencia, Roma, Venecia, Amsterdam, Viena), inclusive de regiones distantes y exóticas (Constantinopla, Jerusalén, Atenas, Nápoles, Palermo, Pompeya, El Cairo, Calcuta, Río de Janeiro). Los viajes eran complicados; el turismo impensable. El hiperrealismo de este género se convirtió casi en una exigencia para compensar con la resolución de situaciones imaginarias de $360^{\circ}$ las ansiedades de un público por querer desplazarse, conocer, escapar, dominar, poseer. El impacto de la ficción de la imagen era traer presente lo ausente. Era reponer ante el espectáculo de la vista espacios y tiempos lejanos. 
Sin duda que la sensación que producían era vicaria. No se trataba de un arte decorativo que llenaba metros de paredes. Se trataba, en el caso específico de las batallas de difundir las gestas militares de las naciones, al tiempo de suscitar sentimientos patrióticos. Los ingrediente melodramáticos y la representación del movimiento eran claves para conmover a los espectadores, además de crear una nueva modalidad de diversión que ordenaba "sensacionalmente” la memoria. El movimiento casi cinemático atrapaba las emociones y producía adhesiones incondicionales. El coup d'oeil era la clave del espectáculo y el dispositivo más eficaz para dotar a la imaginación colectiva de estereotipos y clichés.

Este sublime efecto de lo natural (Comment), aparte de cumplir con lo que sería un “arte documental”, preparaba la antesala del cine y dela televisión. Y es en este sentido que lo que se conoce como "pintura histórica” de este período debe más su razón de ser a todo el auge que adquirieron los temas históricos en los panoramas, dioramas y cicloramas, particularmente de moda en la segunda mitad del siglo XIX cuando empezaron las grandes Exposiciones Universales. Sin embargo, la relación entre la pintura histórica y los panoramas es delicada, y una modalidad no deriva de la otra. Y fue en este despliegue de tendencias que algunos artistas venezolanos fueron becados por el gobierno para hacer sus carreras en Europa, particularmente en París. No sería incongruente suponer que Martín Tovar y Tovar, Arturo Michelena y Cristóbal Rojas (los más destacados en la temática histórica) se contaminaran con este fervor "panorámico". Las guerras franco-prusianas eran una rica fuente de inspiración; París era la capital de las rotondas; y solamente entre 1872 y 1883 fueron producidos 8 panoramas sobre este conflicto bélico. Después de todo, los pintores venezolanos traían justo para la fecha del Centenario los últimos gritos de la moda artística: el proyecto de hacer dentro de los recursos disponibles del país algunos panoramas de las guerras nacionales. Pero... ¿¿de cuáles guerras? ¿Cuál pasado? El asunto se tornaba espinoso.

El país estaba dividido en fracciones políticas irreconciliables desde los primeros tiempos de la República. La Guerra Federal con su líder Ezequiel Zamora fueron los protagonistas de una revolución que configuraba otra Venezuela, morena, mestiza, esclava, pauperizada, que se asimilaba a otros tantos movimientos populares y milenaristas del continente. El fracaso de esta revolución constituyó una zona traumática en el reciente horizonte social del guzmanato. La masa popular traicionada era pasto fértil para cualquier revuelta contra el régimen. Se ponía en juego la apuesta de país ordenado para atraer inversiones e inmigrantes. Por consiguiente, hubo que fabricar-y aquí los plásticos fueron hábiles políticos- un tejido de imágenes historiográficas que, por un lado, representaran e interpelaran a estos sectores populares vencidos con imágenes gratificantes $y$, por el otro, conciliasen las contradicciones y fisuras en torno a un pasado y a una guerra lo suficientemente significativos para contrarrestar la metonimia: la Guerra de la Independencia absorbía la Guerra Federal.

La visión estereoscópica de las imágenes heroicas de los frisos y óleos llamaba fuertemente la atención, y podía con su plasticidad trocar los residuos de frustración de una memoria por intensos sentimientos “patrióticos”, que configurarían otra memoria más favorable al proyecto de la oligarquía liberal. El efecto de relieve que producían las pinturas operaba como troqueles en la textura perceptiva dejando fuertes huellas en la 
memoria residual. Bolívar, en su elegante uniforme napoleónico; Sucre, Páez, Arismendi, Ricaurte, Soublette, Mariño, en sus vistosas casacas prusianas, reemplazaban festiva y suavemente a Zamora: blanqueaban y afinaban el protagonismo social de la historia. Las after-images eran imborrables (Bergson, Dosio).

Así la historia nacional quedó suscintamente concentrada en los años de contienda independentista. La historiografía se abreviaba y magnificaba a la vez entre 1811 y 1824. La conquista y la colonia desaparecían; y después de Carabobo y Boyacá, la República emergía con Guzmán Blanco. El mapa histórico se construía con sustanciales recortes, cuyo precio no sólo fue la higienización de sus actores, sino la borradura de serios conflictos sociales que permanecerían reprimidos en el inconsciente colectivo. La historia se "deshistorizaba”. En este sentido, la exhibición visual del "panorama historiográfico" funcionó como correctivo de la memoria, porque la misma dinámica de las imágenes de la guerra movían oscureciendo zonas, introduciendo olvidos, sustituyendo memorias, elaborando mitos originarios en torno al biografismo de una figura que monopolizaría el horizonte de expectativas. El Centenario del Libertador conducía al ejercicio artificial de la re-memoración de un pasado que se estaba creando allí mismo (Hobsbawm y Ranger, Lowenthal, Fowler).

La centralidad del protagonismo Bolívar/Guzmán en la cultura visual de la Exposición (y de la época) producía imágenes rentables: una de ellas asimilaba el país a las naciones metropolitanas al tener Venezuela también "grandes hombres” que irradiaban la autoridad necesaria para el orden cívico moderno. La otra tenía que ver con la inflación de la "metáfora militar" -no sólo en estos óleos, murales, bronces; sino también en odas, himnos, valses, relatos- en tiempos de paz. Aparte de la recreación ilusoria de un cierto pasado para efectos políticos, la hipertrofia épica, al favorecer la metáfora militar, decía de cuerpos colectivos esforzados en un gesto de lucha sincronizado; ejércitos de hombressoldados, de ciudadanos-soldados compactados bajo una sola voluntad, pero también ordenados para el trabajo sostenido. Así, estos ejércitos y estas batallas se distanciaban cada vez más de las guerras de Independencia; preparaban las sensibilidades de la muchedumbre moderna para otras batallas: eran los ejércitos de obreros para el trabajo industrial, la mano de obra barata para la gran explotación que se avecinaba de los recursos naturales a escala mundial. Estas masas de soldados-obreros mostrábanse dóciles y obedientes: reconocían la autoridad natural del hombre fuerte y de mando.

El orden visual de las cosas en la Exposición maquillaba el lado perverso del discurso historiográfico: después de todo, podía ser un territorio con suficientes masas humanas adiestradas para la explotación desde hacía largo tiempo. Por consiguiente, no fue casual la obliteración de la Conquista y la Colonia. El probable malestar de los sectores populares y trabajadores, que tal vez sí tuvieron conciencia de esclavitudes y abusos, fue hábilmente metamorfoseado bajo los modernos lenguajes de la retórica militar.

El panorama de la guerra fue la clase magistral de un triple disciplinamiento: la audiencia aprendía a mirar y a memorizar las imágenes sin el dictamen del maestro ni del libro, ordenaba la imaginación histórica y canalizaba las pasiones políticas, y preparaba el contexto de multitudes organizadas y obedientes para una sociedad totalitaria que no contraviniera las tendencias del mercado internacional. 
Aquí los libros sólo se ven

La letra impresa tenía muchas décadas circulando básicamente en forma de periódicos, folletos, pasquines, volantes, hojas sueltas... El libro como tal constituía una rareza; un objeto de lujo, una pieza exclusiva, que muy pocos adquirían, que a muy pocos les interesaba adquirir. Se sabía de gente de “apellido” que tenía en su haber grandes bibliotecas heredadas desde los tiempos coloniales. La cosa "libro" no estaba específicamente en el mercado-tampoco existían librerías-, si acaso en alguna quincallería o pulpería había alguno que otro ejemplar -tal vez las novelas de Víctor Hugo, Chateaubriand, El contrato social de Rousseau- entremezclado con lociones, licores, sedas, zapatos, relojes, sombreros importados de Francia e Inglaterra. Durante los nuevos tiempos de la República, y para las crecientes capas medias urbanas, el ir disponiendo de un pequeño aparador con unos cuantos volúmenes -los más frecuentes eran los de catecismo, lecciones de moral y buena conducta, hagiografías, historia patria-era un signo de acomodo social, que decía de un estado de “decentización” de la familia; la letra tenía el mágico efecto del blanqueamiento. Pero los libros escaseaban: por ejemplo, entre 1830 y 1875 apenas se habían publicado en Venezuela 516 títulos, producción que bajaba notablemente a 30 títulos en aquellos lustros de turbulencia política (Silva Beauregard 64). Sin embargo, el período del guzmanato vio una revolución estelar en el ramo editorial.

Las dos siguientes salas de la Exposición Nacional fueron destinadas tanto a la maquinaria y tecnología que producía la cultura impresa como sus resultados: montones de libros, grandes y gruesos volúmenes, lujosas encuadernaciones en cuero repujado, con ribetes y lomos dorados, con diferentes clases de papel, todo para mostrar objetivamente el progreso alcanzado por el gobierno del Ilustre Americano. La imprenta La Opinión Nacional de Fausto Teodoro de Aldrey hacía gala de las nuevas técnicas de encuadernación; la tipografía “El Cojo” de J.M. Herrera Irigoyen había adquirido también nuevas máquinas de impresión, que retarían a las bibliotecas de los sectores medios con la futura publicación de El Cojo Ilustrado, revista que ilustraría profusamente sus páginas con fotografías y grabados. Así que los libros allí expuestos eran para ser (ad)mirados. Ahora aparecían envueltos en un universo de máquinas que los producían. Eran cosas hechas por otras cosas. Se exhibían entre máquinas: imprentas, litografías, tipografías, máquinas para la fabricación de papel, máquinas y aparatos para la encuadernación, máquinas para la fundición de tipos; estereotipia, impresiones litográficas de toda clase; tintas de imprimir, de escribir, de marcar; papel de escribir, de imprenta, de dibujo, de colores, de envolver, secante; artículos para pintura, dibujo de planos, acuarelas; y libros en blanco, rayados, y de contabilidad comercial.

Ahora las máquinas podían producir miles de ellos; serializarlos; abaratar sus costos; mecanizar la encuadernación, con lo cual los lectores se ahorrarían el trabajo de armar sus propias colecciones en álbumes. ¡La variedad del mercado tipográfico hasta prometía libros a todo color! Con ello tal vez se conseguiría ampliar el universo lector y hacer más atractiva la lectura. Se produciría un cambio sustancial en la aproximación a la cultura del impreso. El objeto libro, con sus tapas duras, abrazaba muchas hojas y un mayor y más continuo horizonte discursivo. Sin duda, la tecnificación del libro democratizaría saberes desacralizando, por un lado, la biblioteca; pero, por el otro, como mercancía serializada, 
ingresaría en otro orden -el mass mediático- que provocaría a su vez la banalización de la cultura letrada, o al menos versiones trivializadas de la alta cultura impresa. No hay que perder de vista que Guzmán Blanco tuvo un interés primordial, apenas asumido el poder en 1870, en decretar la "Instrucción Primaria Pública” como “Obligatoria” e impulsar la alfabetización: entre la exhibición de libros, no fueron pocas las muestras de textos y útiles escolares. En todo caso, las novedades tecnológicas en este ramo podían reproducir en las páginas de libros fotografías de las pinturas y de los objetos que se habían visto, por ejemplo, en las salas de la Exposición. De pronto parecía producirse una contigüidad entre la "alta” y "baja” cultura, un aparente impulso de horizontalización entre manifestaciones elitescas, oficiales, “cultas”, y las masivas, cotidianas, “populares”. El espacio y dinámica de la Exposición creaba -y no sin tensiones- ese efecto de convivencia niveladora

La oficialidad cuidó la selección de libros que debieron configurar el corpus de las letras nacionales. Después de todo era la literatura el lenguaje que confería legitimidad a una nación moderna. Letras eran civilización; libros progreso. Había que armar la representación de la biblioteca, y la biblioteca que representase a la nación. En este punto, el evento de la Exposición constituyó un momento de diseño fundacional en el canon de las letras, y un lugar que posibilitó articular tanto la historiografía literaria como canonizar los textos que pasarían a formar parte del capital de la institución literaria. A pesar de la maquinización que popularizaría los saberes, el poder del libro regulaba los discursos. El fantasma de la vieja tradición bíblica reestablecía el orden y jerarquía de la palabra. A través del libro, hablaba la ley del padre, el estado. No se incluyeron voces femeninas. Sólo se expresaron los géneros "duros" (memorias, estadísticas, censos, códigos, decretos, anales, discursos, biografías, diccionarios, manuales, historias, cuentos, epopeyas, odas, himnos), aquellos que bien podían representar con sus obras el patrimonio nacional. Las letras eran un asunto público, un ejercicio de hombres, del mismo modo que la elaboración de imágenes épicas en óleos y murales. Por consiguiente, sólo algunos libros fueron objetos de exhibición, los libros-monumento, que por su asunto eran representativos de la agenda patriótica. Entre ellos, por ejemplo: los 14 volúmenes de Documentos para la historia de la vida del Libertador de Ramón Azpúrua, o los 18 volúmenes de Memorias de O’Leary, o los 4 volúmenes de Biografías de hombres notables de Hispanoamérica, o los 4 volúmenes de Datos Históricos Sur-Americanos de Antonio Leocadio Guzmán, o los volúmenes de Memorias de los Ministerios y Leyes Nacionales, y finalmente, los volúmenes "literarios”: Venezuela heroica y Zárate de Eduardo Blanco; Orígenes de la Revolución venezolana de Arístides Rojas, la Obra poética de Francisco Guaicaipuro Pardo, las Poesías de Ramón Yépez, los poemas épicos La Bolivíada y La Colombiada, el drama Triunfar con la Patria, y Perfiles venezolanos o Galería de hombres célebres de Venezuela en las letras, ciencias y artes de Felipe Tejera, los 2 volúmenes de Literatura Venezolana de Hortensio; los Ensayos sobre el arte en Venezuela de Ramón de la Plaza; los 3 volúmenes de El Zulia literario, un Diccionario de voces indígenas, ofrenda de la tipografía "El Cojo”, y textos escolares sobre moral e instrucción religiosa, geografía e historia.

Los preparativos de la Exposición Nacional en 1883 crearon condiciones favorables para hacer coincidir en la fecha del Centenario manifestaciones culturales que, cobijadas bajo un espíritu enciclopédico y afán coleccionista, arriesgaron un esfuerzo 
omnicomprensivo de la historia (manifestado en los libros) y de los recursos y potencialidades del país (expresado en el Palacio).Y en este orden, las fechas de la Exposición catalizaron los primeros esfuerzos en producir un panorama articulado de la literatura nacional. Surgía la crítica e historiografía literarias dentro de una voluntad que ligaba el impulso acumulativo de la economía liberal con los índices del progreso (Tenorio Trillo, González-Stephan, “Coleccionar y exhibir...”).5

El Palacio gótico y los libros se complementaban; el edificio era la versión en piedra deVenezuela heroica, Orígenes de la Revolución, Documentos de la vida del Libertador, La Bolivíada, La Colombiada, los Perfiles venezolanos, los Ensayos sobre el arte, o la monumental Literatura Venezolana de Hortensio. El mismo impulso abarcador y totalizante, el mismo principio que procedía por acumulación aditiva, la misma gramática reiterativa, animaba tanto a la Exposición como a los libros. Su voluminosidad escondía la misma operación del museo-almacén diluyendo las temporalidades históricas por el atiborramiento de fechas, de obras, de hombre ilustres. Se desmorfologizaba la historiografía, para construir con el discurso catalográfico -que clasificaba- series análogas crono-lógicas.

Particularmente la historiografía literaria tuvo en este sentido varias responsabilidades decisivas, al intervenir en el campo político a partir de las ficciones que podía sostener la retórica. El caso de la Literatura Venezolana. Revistas Biliográficas expresamente escritas para La Opinión Nacional. Homenaje a Bolívar en su Centenario fue sintomático. El autor español José Guel y Mercader, bajo el seudónimo de Hortensio, reunió en dos gruesos volúmenes una serie de reseñas de personalidades venezolanas que habían sido publicadas en el periódico del gobierno. Sin embargo, eligió la figura de Simón Bolívar como eje vertebrador de la identidad de las letras y también como centro originario de la historiografía literaria, alrededor del cual se disponían los demás hombres de letras. La elección de Bolívar parecía casi natural, más en el régimen guzmancista. Pero Guel y Mercader rehizo con Bolívar un nuevo mapa de relaciones internacionales, altamente favorables, por un lado, para la restitución de los lazos con la antigua Madre Patria y, por el otro, para legitimar a través de la lengua castellana la consaguinidad eurocéntrica de la nacionalidad venezolana. Dentro de una plataforma que caracterizaría las gestiones diplomáticas de la España finisecular en su recuperación de las excolonias, Guel y Mercader decidió “olvidar”, con el mutuo consentimiento de las partes interesadas, la conquista y colonia. El crítico español dotó así al Libertador de una genealogía libresca ("literaria”) que permitió higienizar a la ciudadanía criolla; pero también: uno, legitimar el castellano como la lengua de la literatura nacional, cuidando en reunir aparte los

\footnotetext{
${ }^{5}$ Ciertamente el Centenario en 1883 promovió la producción historiográfica. Sin embargo, tuvo antecedentes que abonaron el terreno: el trabajo de José A. Pérez Literatura patria (1864), Juan Vicente González con su Revista Literaria (1865), el volumen de José María Rojas Biblioteca de Escritores Venezolanos Contemporáneos (1875), Juan Piñango Ordóñez publicó un ensayo "Literatura patria" (1875) en La Tertulia; los Perfiles venezolanos (1881) de Felipe Tejera, Literatura Venezolana (1883) de José Guel y Mercader; también Literatura venezolana (1883) de D. Ramón Hernández, Julio Calcaño en 1888 su Reseña histórica de la Literatura Venezolana, el Parnaso Venezolano (1892) de Julio Calcaño, en 1895 el Primer Libro Venezolano de Literatura, Ciencias y Bellas Artes, “La literatura venezolana” (1904) de José Gil Fortoul, y finalmente en 1906 La Literatura Venezolana en el Siglo XIX de Gonzalo Picón Febres.
} 
vocablos indígenas en un Diccionario para descontaminar la lengua oficial y, dos, recuperar los límites del antiguo imperio a través de la hegemonía hispánica. El Hispanismo fortalecía identidades blanqueadas facilitando etnografizar a las culturas indígenas y, desde luego, hacer desaparecer el legado negro. El diseño gótico del Palacio no hacía sino refrendar también otros prestigios medievales: los de la meseta castellana.

Para cerrar las reflexiones de esta visita a la Exposición Nacional, volvamos otra vez a la cultura de los panoramas. Si bien, como acabamos de señalar, la historiografía fue un ejercicio ligado a las esferas de la cultura letrada estatal, la forma monumental en que estructuró sus contenidos los debió más a ciertas modalidades de la cultura visual y a la nueva cultura material de los pasajes y galerías. También en este caso las conexiones son delicadas. No se pueden derivar tan simplemente los “panoramas literarios” o las “galerías de hombres célebres” de esa cultura de masas. Ambas manfestaciones se hermanaban por el mismo espíritu burgués de capitalización de bienes simbólicos. Fueron los tiempos. Los panoramas literarios son “fisiologías”, como galerías de retratos de tipos. Se cruzaban aquí varias prácticas de consumo cultural: el inventario informativo, el daguerrotipo, el panorama, el género de tipos y la cultura del fragmento en el "baratijo callejero".

¿Cuánto le debe la alta cultura y la historiografía a las formas de la cultura visual y masiva? Con exactitud no lo sabremos; pero de hecho las Exposiciones fueron espacios donde las distancias se pusieron a prueba y las distinciones contaminaron sus diferencias. Y sin duda configuraron espacios donde el ojo de las capas medias empezó a leer la cultura de la modernización de modo más eficiente que a través de la biblioteca.

BibLIOgRAFÍA

Almandoz Marte, Arturo. Urbanismo europeo en Caracas (1870-1940). Caracas: Fundarte y Ediciones Equinoccio, 1997.

Benedict, Burton. “International Exhibitions and National Identity”. Anthropology Today 6 (1991): 5-9.

Benjamin, Walter. "El Flaneur”, “Daguerre o los Panoramas”, “Grandville o las Exposiciones Universales”. Poesía y capitalismo, Iluminaciones II. Madrid: Ediciones Alfaguara, 1993.

Bergson, Henri. Matter and Memory. Nueva York: Zone Books, 1988.

Castellanos, Rafael Ramón. Caracas 1883 (Centenario del Natalicio del Libertador). Caracas: Academia Nacional de la Historia (Estudios, Monografias, Ensayos), vols. 33 y 34.1983.

Clark, T.J. The Painting of Modern Life: Paris in the Art of Manet and His Followers. Princeton: Princeton University Press, 1984.

Comment, Bernard. The Painted Panorama. Nueva York: Harry N. Abrams, Inc., 2000.

Crary, Jonathan. Techniques of the Observer. On Vision and Modernity in the Nineteenth Century. Cambridge: MIT Press, 1992. “Spectacle, Attention, Counter-Memory”. October 50 (1989): 97-107.

Crinson, Mark. Empire Building. Orientalism and Victorian Architecture. Nueva York: Routledge, 1996. 
D’Arcy Wood, Gillen. The Shock of the Real. Romanticism and Visual Culture, 17601860. Nueva York: Palgrave, 2001.

Debord, Guy. The Society of Spectacle. Nueva York: Swerre Editions, 1994.

Déotte, Jean-Louis. Catástrofe y olvido. Las ruinas, Europa, el Museo. Santiago de Chile: Editorial Cuarto Propio, 1998.

Díaz Sánchez, Ramón. Guzmán, elipse de una ambición de poder. Caracas: Ministerio de Educación Nacional, 1950.

Dosio, Patricia Una estrategia del poder: La Exposición Continental de 1882. Buenos Aires: Universidad de Buenos Aires, Serie Hipótesis y Discusiones, 1998.

Ernst, Adolfo. La Exposición Nacional de Venezuela en 1883. Obras Completas. Vols. III y IV. Caracas: Fundación Venezolana para la Salud y la Educación, 1983.

Esteva Grillet, Roldán. Guzmán Blanco y el arte venezolano. Caracas: Academia Nacional de la Historia, serie El libro menor, 1986.

Foster, Hal (Ed.). Vision and Visuality. Seattle: Bay Press, 1988.

Fowler, Peter. The Past in Contemporary Society. Londres: Routledge, 1992.

Foucault, Michel. Vigilar y castigar. Nacimiento de la prisión. México: Siglo XXI Editores, 1976.

García Canclini, Néstor. Consumidores y Ciudadanos. Conflictos multiculturales de la globalización. México: Grijalbo, 1995.

Gasparini, Graciano y J.P. Posani. Caracas a través de su arquitectura. Caracas: Fundación Fina Gómez, 1969.

González-Stephan, Beatriz. "Coleccionar y exhibir: la construcción de patrimonios culturales”. Hispamérica 86 (2000): 3-17. “Con hilo y aguja: el tejido de la otra memoria”. Arrabal 4 (2002): 97-111.

"A Gothic Glass Case in the Tropical Forest: The First Venezuelan National Exhibition of 1883”. Victorian Prism. Joseph Childers, ed. Virginia: Virginia University Press (en prensa).

Gruzinski, Serge. La guerra de las imágenes. De Cristóbal Colón a "Blade Runner" (1492-2019). México: Fondo de Cultura Económica, 1994.

Hamon, Philippe. Expositions: Literature and Architecture in Nineteenth-Century France. Berkeley: University of California Press, 1992.

Hamon, Philippe. "Images à lire et images à voir: 'images américaines' et crise de l’image au XIXe siècle (1850-1880)”. Usages de l'image au XIXe siécle. Stéphane Michaud, Jean-Yves Mollier y Nicole Savy, eds. París: Editions Créaphis, 1992. 235-46.

Hobsbawm, Eric y Terence Ranger (Eds.). The Invention of Tradition. Nueva York: Cambridge University Press, 1983.

Jay, Martin. “Scopic Regimes of Modernity”. Vision and Visuality. Hal Foster, ed. Seattle: Bay Press, 1988. 3-27.

Kantorowicz, Ernst. The King's Two Bodies. Princeton: Princeton University Press, 1957. Karp, Ivan y Steven D. Lavine (Eds.). Exhibiting Cultures. The Poetics and Politics of Museum Display. Washington: The Smithsonian Institution Press, 1991.

Leprun, Sylviane. Le Théatre des colonies: Scénographie, acteurs et Discours de l’imaginaire dans les expositions, 1855-1937. Paris: Ediciones L’Harmattan, 1986. 
Lowenthal, David. The Past is a Foreign Country. Cambridge: Cambridge University Press, 1985.

Martí, José. La Exposición de París. La Habana: Centro de Estudios Martianos. Edición crítica de Salvador Arias, 2001.

Obras Completas. "Nuestra América”, VIII. La Habana: Editorial Nacional de Cuba, 1963.

Obras Completas. "En los Estados Unidos”, XII. La Habana: Editorial Nacional de Cuba, 1964.

Martín Barbero, Jesús. Los ejercicios del ver. Hegemonía audiovisual y ficción televisiva. Barcelona: Gedisa, 1999.

Oettermann, Stephan. The Panorama. History of a Mass Medium. Nueva York: Zone Books, 1997.

Pomian, Krzysztof. “Musée, nation, musée national”. Le Debat 65 (1991): 166-75.

Richards, Thomas. The Commodity of Culture of Victorian England. Advertising and Spectacle, 1851-1914. Stanford: Stanford University Press, 1990.

Silva Beauregard, Paulette. Una vasta morada de enmascarados. Caracas: Fundación Casa de Bello, 1993.

Stewart, Susan. On Longing. Narratives of the Miniature, the Gigantic, the Souvenir, the Collection. Baltimore: The Johns Hopkins University Press, 1984.

Stone, Peter y Brian L. Molyneux (Eds.). The Present Past: Heritage, Museums, and Education. Nueva York: Routledge, 1994.

Tenorio Trillo, Mauricio. Artilugio de la nación moderna. México en las exposiciones universales, 1880-1930. México: Fondo de Cultura Económica, 1998.

Tester, Keith (Ed.). The Flaneur. Nueva York: Routledge, 1994.

Virilio, Paul. La máquina de la visión. Madrid: Cátedra, 1989. 